Article

\title{
Religion as Animal and Alive
}

\author{
Paul Waldau \\ Graduate Program in Anthrozoology, Department of Animal Behavior, Ecology and Consercation, \\ Canisius College, Buffalo, NY 14208, USA; pwaldau@gmail.com
}

Received: 9 April 2019; Accepted: 26 May 2019; Published: 30 May 2019

\begin{abstract}
The notion of "living religion" is helpful in exploring how individuals and communities have across time and culture engaged their other-than-human neighbors in a local place as a response to the fact that each human individual clearly lives in a more-than-human world. Threads of observation and argument are woven together to suggest that focusing on nonhuman animals helps any human sustain the vibrant, living quality that so often has been a hallmark of a relevant and healthy religious/spiritual awareness.
\end{abstract}

Keywords: animals; animals and religion; animal ethics; species; animal studies; nature

I speak here of a heartbeat in religion that is animal and alive-what I will call "living religion." I do so by interweaving seven threads of argument. My purpose is to illustrate how religious individuals and communities can engage their other-than-human neighbors in a local place shared by both human and nonhuman animals. As a woven braid, these threads tie together issues that arise as members of our species have, across time and place in personal decisions and through their own religious communities and traditions, attempted to deal with the fact that each human individual clearly lives in a more-than-human world. These intertwined lines of discussion work together to raise the question of how focusing on nonhuman animals helps any human sustain the vibrant, living quality that so often has been a hallmark of a relevant and healthy religious/spiritual awareness. The overall thrust of these generalizations, then, is to make clear that an individual or community practicing a spiritual tradition can, through daily practices in a local place, notice and take seriously both human and nonhuman neighbors.

The term "living religion" is asked to do special work in this essay, for the task I give this term is different from the ordinary, obvious thrust of this phrase as a designation of those religions that "continue to have followers today." I mean something different by "living religion," namely, a religious or spiritual practice that ordinary people in daily life use to respond to the key challenges of human life. There are, to be sure, many uses of the term "living religion." The sense I use has affinities with definitions focused on daily life, such as "how ordinary people engage, express, create, and otherwise make use of religion and spirituality in the contexts of their everyday lives" (Santa Clara University n.d.), but goes further through an emphasis on daily practices in a local place that nurture each human's native abilities to notice and take seriously both human and nonhuman neighbors.

The work I ask "living religion" to do in this essay thereby shares some features with the notion of "lived religion" developed at the end of the twentieth century by scholars in reliance on work done in the French tradition of the sociology of religion (la religion vécue) regarding the textures and contours of religion in the daily, local life of ordinary people (Hall 1997, p. vii; Orsi 1985).

With such emphases, I hope to spotlight religious and spiritual practices that are, plainly said, unresponsive to the central needs of contemporary humans. These references to "central needs" and "key challenges of human life" faced "in everyday lives" are meant to direct the reader's attention to those challenges each human in the twenty-first century faces in becoming a responsible member and "plain citizen" of the Earth community (Leopold 1991, p. 240). These challenges are many, including at least the following: 
(i) being one intelligent animal among others, each of whom has but a subset of the "multiplicity of intelligences" (Tucker 2006) that grace our more-than-human earth;

(ii) seeing the beauty and mystery in the fact that we are but one of the Earth's bearers of consciousness;

(iii) being responsive to our own and other animals' realities, nurturing an intentional relationship to present place and moment as an open door to fellow living beings, humans and nonhumans alike, that any human individual is capable of noticing and taking seriously and thereby deepening our animal-based capabilities for awareness, connection, community and place;

(iv) nurturing a stance of openness to discovery of additional, unexpected complexities such as intelligence, various forms of friendship and community, and sensibilities to the world that sometimes far exceed the sensibilities that are humans' natural endowment;

(v) being realistic about human finitudes in the matter of knowing and judging other living beings, and thereby learning to tolerate difference, nuance, and the unexpected discovery; and,

(vi) working toward complete frankness about humans' finitudes and limits as they have manifested in different forms of violence done in the name of religion; examples of such violence are typically drawn from religious traditions' involvement in human-on-human harms, but equally important examples can be identified in the ways religious institutions continue to accept without question, even support vigorously, modern societies' intentional harms to nonhuman animals, such as factory farming or the destruction of wildlife communities and habitats, both of which reflect a failure of the human spirit caused by the modern subordination of nonhuman lives for human advantage-living religion admits these harms, and challenges them.

This essay's sense of "living religion," then, is meant to nurture an intentionality that can help each of us engage this imposing suite of challenges. Through such intentionality, living religion enables individual humans to accept other living beings' abilities on their terms, whether those other living beings be human or nonhuman, for living religion needs to respond to real lives in order to be alive itself. When a religion fails to be responsive in this way, it becomes subject to the all-too-familiar phenomena of legalistic, absolutist, reactionary and intolerant forms of religion that have so often deadened daily human life and thus religious/spiritual awareness. Such unresponsive forms of daily religious life also have a further risk, namely, failing to challenge problems that arise when unjust laws or other social constructions imposed by one group of humans on another reduce the subordinated humans' ability to meet basic needs.

As the term is used here, then, "living religion" helps humans "understand things better and learn to see reality as it is." (Vroom 1993, p. 120) It does this by prompting each of its followers to learn how to recognize and work with obvious truths, such as humans' animality, or the complex forms of awareness exhibited by many nonhuman animals as they live out their lives independent in every way of human lives. Such a living religion thereby models for humans what it means to be a responsible citizen in a more-than-human world.

The Seven Threads. The individual threads woven together in this essay can be summarized as follows.

1. Engaging nonhuman neighbors is a long-standing hallmark of a living religious sensibility.

2. Living religion is an engagement with our local place as the intersection of the many nested communities to which each human belongs.

3. Living religion fosters a stance of openness to the possibility of unlearning those inherited images that contract rather than expand our understanding of caring for others.

4. Living religion affirms spirituality as this worldly.

5. Religious thinking about other living beings will be richer if it is anchored in good factual, observation-based information.

6. Religiously inspired claims about humans' relationships with other living beings will inevitably reflect humans' own animal abilities and finitudes. 
7. The achievements we know as our species' "religions" and "spiritual traditions" are in fact the creation of animals.

\section{Engaging Nonhuman Neighbors Is a Long-Standing Hallmark of a Living Religious Sensibility}

Noticing and taking seriously one's neighbors who happen to be nonhuman animals is one way that religious sensibilities can manifest in quotidian acts and local places. Thereby, such encounters (i) invest religious awareness with relevance to particular places, and (ii) spur awareness of the shape and consequences of our choices in daily life. In both ways, such a "living" religious sensibility promotes ordinary life choices that nurture self-transcending awareness of a kind that may be named "spiritual" even as it also enriches both one's local community and the larger tradition to which the individual or community may belong.

It is a given in many modern religious traditions that encounters with other humans are a chrysalis allowing growth beyond one's self-centered concerns-but how might engaging nonhuman neighbors do this? Consider the question "Who are my neighbors?" Each of us lives out the majority of our days in a specific, local place (perhaps our home, or local community/neighborhood). For those willing to notice, each such locale is home to a unique subset of the world's animals-these living beings are our own neighbors in the obvious sense that they live near us in our local place. Notoriously, the free-living nonhuman neighbors we know as "wildlife" are difficult to see, let alone know well. This category does not include those domesticated nonhuman animals often referred to as "companion animals," nor does it include those animals we have subjected against their will to food production or zoo-based captivity. Neighboring wildlife is, because of these animals' free-living status, hard for us to "know well" in the sense of fathoming what their actual lives might be like. But these neighbors do impact us by appearing now and then, here and there, and if we recognize our ignorance about these living beings, this acknowledgment of our own limits can stimulate us in important ways. One of the twentieth century's surpassingly gifted interdisciplinary thinkers observed,

Even with all our technological accomplishments and urban sophistication we consider ourselves blessed, healed in some manner, forgiven and for a moment transported into some other world, when we catch a passing glimpse of an animal in the wild: a deer in some woodland, a fox crossing a field, a butterfly in its dancing flight southward to its wintering region, a hawk soaring in the distant sky, a hummingbird come into our garden, fireflies signaling to each other in the evening. (Berry 2006, p. 7)

With its invocation of "blessed," "healed," "forgiven" and "transported," this observation sounds deeply religious overtones. Consider more particularly how such encounters with nonhuman neighbors lure us into possibilities that are encapsulated in this startling claim by Viktor Frankl, "self-actualization is possible only as a side-effect of self-transcendence." (Frankl 1992, p. 115)

Nonhuman neighbors move us in ways that the human community alone cannot-they invite us to recognize ourselves as one animal among others in a larger, more-than-human community that occupies a local ecosystem and the Earth as whole. By noticing this invitation, we go through a door to transporting, mysterious and multi-valent realms.

When we choose to be fully aware of even the simplest features of our inevitable encounters with other living beings, we notice that our attention is drawn by the open and uncertain character of this being ... This is precisely what enables our senses to really engage and participate in this encounter. Another being, and indeed any entity that captures the gazer, is never revealed in its totality-there are always facets of the being that do not present to our human eyes or noses or general awareness. This is our finitude-and the result is a fundamental withholding of aspects of the encountered being from our direct apprehension. (Abram 2010, p. 259) 
It says much about the human community that, for most if not all of us, wild or free-living nonhumans can be inviting-such invitations open us to appreciating not only the presence of our nonhuman neighbors and our finite abilities to know them fully, but also our own curiosity and even our self-awareness.

Think of the multiple ways this is true of any encountered other-a red maple, a bat, a wasp, a deer walking on "our property." ... We see none of these in their entirety. We may ignore this-but in that case, our ignorance takes on self-inflicted features that are truly debilitating for ourselves and the beings we ignore. This tension between the apparent and the hidden dimensions of each being beckons steadily to my perceiving body, provoking the exploratory curiosity of my senses. (Abram 2010, pp. 44-45)

And as awareness of our own curiosities and finitudes is noticed, we foray outside our self-interest and the heavy emphasis that our modern world and its institutions put on exclusively human interests. In encounters with other living beings, then, a door to self-transcendence is opened and a journey toward fuller actualization and awareness can begin.

Those who choose to explore other animals' lives can, as our long human history attests, discern something of a nonhuman neighbor's life, perhaps even personality-admittedly, in the local setting, we are quite limited as to what we can know. But we are not all ignorance. We can guess a few basics—shared place, shared animality, perhaps shared curiosity. There are, without question, obvious limits, for most of such a "neighbor's" life will be hidden from us in ways captured by David Abram's observation that "No matter how long I linger with any being, I cannot exhaust the dynamic enigma of its presence." (Abram 2010, p. 45) Neighbors of this ilk, then, "have nothing less than a vivacious presence for us, disclosing a shared animality even as they bear some essentially inaccessible features that may appear in the guise of mystery, ignorance, or simple silence." (Waldau 2013, p. 259) The very presence of these neighbors poses questions that have much more power than their answer-they not only "ask us in what ways are humans unique, or even a paradigm of possibility?" but also "prompt us to wonder about their place, as well as our own, in the world we share." (Waldau 2013, p. 259)

If we ruminate about such invitations from nonhuman neighbors, we soon encounter a number of important gifts that living in a more-than-human world affords us-we learn that we have many diverse kinds of nonhumans in our local world. We also learn that our education has not provided us with much in the way of specific details about these neighbors. Our journey of self-transcendence soon helps us recognize that our inherited impressions are inadequate to the task of meeting our nonhuman neighbors. Most important for our ethical natures, a further invitation to discovery awaits us-we are characteristically so ignorant about other-than-human lives in our local world that we can, if we notice our own ignorance about these neighbors, begin to interrogate human exceptionalism, a harmful narrative that today has become the linchpin of so much in our modern, industrialized societies, including not only the rhetoric of our mainline religious traditions, but also our laws, sciences, education, and notion of what constitutes "moral" behavior.

Human exceptionalism is the claim that humans are, merely by virtue of their species membership, so qualitatively different from any and all other forms of life that humans rightfully enjoy privileges over all of the earth's other life forms. Such exceptionalist claims are well described [by the moral philosopher Rachels] as "the basic idea" that "human life is regarded as sacred, or at least as having a special importance" such that "non-human life" not only does not deserve "the same degree of moral protection" as humans, but has "no moral standing at all" whenever human privilege is at stake. (Waldau 2013, p. 8; Rachels 1991, p. 86)

Many forms of religion familiar to people today have advanced this extraordinary exclusion. But we are also heirs to another unassailable fact-through the millennia of human experience needed for members of our species to develop the power and range of our present collective presence, human 
exceptionalism was clearly not the norm. Instead, such exclusions were repudiated as out of touch with who and what humans most truly are, namely, a full member of the larger community comprised of all living beings. As heirs to this animal-inclusive tradition, each of us has access to many examples of living religion. Luther Standing Bear, an Oglala Lakota, reflected in 1933 on the understanding of other living beings that was a centerpiece in his people's oral tradition.

The animal had rights - the right of man's protection, the right to live, the right to multiply, the right to freedom, and the right to man's indebtedness-and in recognition of these rights the Lakota never enslaved the animal, and spared all life that was not needed for food and clothing. ... [T]he old Lakota was wise. He knew that man's heart, away from nature, becomes hard; he knew that lack of respect for growing, living things soon led to lack of respect for humans too. So he kept his youth close to its softening influence. (Luther Standing Bear 1998, pp. 205-6)

Such views prevailed among the vast majority of every human's ancient forebears, an aspect of our complex heritage that invites our wonder about the ways that other animals might spur us today to recognize both them and ourselves as citizens of a more-than-human world.

Meditation on animals and our relations with them must be very nearly the oldest and most persistent form of human pensiveness; it is doubtful that we could ever really adequately know our identity as humans if we did not have other animals as a frame for our own activity and reflectivity. (Fernandez 1995, p. 8)

We can learn from this ancient heritage, particularly as it contrasts with the human exceptionalism that now dominates modern education and institutions.

While persons brought up within literate culture often speak about the natural world, indigenous, oral peoples sometimes speak directly to that world, acknowledging certain animals, plants, and even landforms as expressive subjects with whom they might find themselves in conversation. Obviously these other beings do not speak with a human tongue; they do not speak in words. They may speak in song, like many birds, or in rhythm, like the crickets and the ocean waves. They may speak a language of movements and gestures, or articulate themselves in shifting shadows. Among many native peoples, such forms of expressive speech are assumed to be as communicative, in their own way, as the more verbal discourse of our species (which after all can also be thought of as a kind of vocal gesticulation, or even as a sort of singing). Language, for traditionally oral peoples, is not a specifically human possession, but is a property of the animate earth, in which we humans participate. (Abram 2010, pp. 10-11)

We can consider as well whether today we need to unlearn certain biases-for example, any approach that refuses to consider the mere idea of any nonhuman animals as bearers of consciousness, capable of complex forms of intelligence, subject to emotions and more. Many humans today, without evidence, facilely assume such features must be solely the birthright of human animals. Such a refusal to inquire has prevailed because twentieth century education and other powerful domains, including mainline religious institutions, were consistently inhospitable to such a possibility. Consider an example that represents well the dominant narrative in not only most established religious institutions, but also the experimental traditions of many exclusively secular sciences and the vast majority of education-based teaching about ethics and morality, legal systems, and the business community. This example, drawn from a mid-1990s revision of the Catholic Catechism, puts limits on compassion, a central concern of the Abrahamic traditions rooted in the ancient Hebrew recognition of other living beings as fellow creatures.

It is contrary to human dignity to cause animals to suffer or die needlessly. It is likewise unworthy to spend money on them that should as a priority go the relief of human misery. 
One can love animals; one should not direct to them the affection due only to persons. (Catechism of the Catholic Church 1994, p. 2418)

Reasoning that human compassion regarding all of one's nonhuman neighbors should be constricted whenever human misery exists treats compassion as a human-first phenomenon. The central claim that only "persons," that is, members of the human species, really matter is allowed to dominate, thereby affirming the unstated background understanding that all other animals are rightfully subordinated to human needs and desires. Such a major revamping of our ethical awareness would have astonished our most ancient forebears. As explained below, each of us lives within a local world that is far removed from human affairs on the other side of our shared planet. While the affairs of such humans surely matter, those who develop the capacity to ignore local, nonhuman suffering on the basis of such human-centered reasoning constrict their daily abilities to care about neighbors. Thereby an abstract, arid human exceptionalism prevails in one's local world. Such a modification of the long-standing duty of compassion is "business as usual" in the modern world's industrialized and post-industrial societies.

It is, then, not only our encounters with other animals that invite us to reflection. So does the prevailing narrative of human exceptionalism. Both prompt us to ask, does human exceptionalism reflect human genius or human arrogance? One of the twentieth century's surpassingly gifted philosophers suggested that "All real living is meeting." (Buber 1958, p. 11) We can ask, "meeting whom?" Everyone has forebears who answered this question with astonishing breadth. This is so because among indigenous cultures, not only individual identity but also communal identity was born and thrived through what one anthropologist names "relational epistemology." (Bird-David 1999, p. 78) Such knowing of oneself is not exclusively human-centered, as is the case with the Cartesian self-focused "I think, therefore I am." Rather, we learn about ourselves and community relationally—-this same anthropologist suggested alternative, more discerning ways to frame what it means to be a reflective animal individual: "I relate, therefore I am" or "I know as I relate." (Bird-David 1999, p. 77) Here is the basis for the claim "all living is meeting," for each person lives through relationships that feature a "mutual responsiveness", which can, when noticed and taken seriously, grow into "mutual responsibility." (Bird-David 1999, p. 77) This is why engaging nonhuman neighbors has so often been a hallmark of a living religious sensibility.

\section{Living Religion Is an Engagement with Our Local Place as the Intersection of the Many Nested Communities to Which Each Human Belongs}

Consider a further power conferred on us by asking "Who are my neighbors?", namely, the issue of engaging a local place as a world in which we notice that we are, in fact, members of an entire series of nested communities. Although, in our highly industrialized societies, many have lost a sense of place, as animals, it is in our very being to notice place. Think of how obvious the following insight is to the human heart and mind, "there never was an is without a where." (Buell 2011) The implications are wide and deep. For any embodied being, and thus for humans and all other animals, there never was, and never can be, an "is" without a "where." Recognizing the centrality and fullness of place in our lives helps one to notice a key feature of our human animal lives-each day, we encounter our own animality in each breath, meal, and step, encounter with family and friends, fear or hope, and so much more.

At other times, the traces of our animality are consequential shadows, such as those created by the dysfunctions that result from the self-inflicted ignorance foisted on us by human exceptionalism's many powerful dismissals and refusals to notice our membership in a more-than-human community. Even in the darkness created by such shadows, enticing glimmers appear, as hinted at in Thomas Berry's observation that mere encounters with local wildlife can leave one "blessed," "healed," "forgiven", even "transported."

We also encounter unique valences of our animality in seemingly abstract notions that dominate science-we are, taxonomically, as fully great apes as are gorillas, orangutans, bonobos and chimpanzees. Humans are, as a group, also but one of several hundred primate species, and merely one of several 
thousand mammal species. In our archeological sciences, we recognize that ancient humans interacted constantly with the surrounding nonhuman animals, and in our comparative efforts to see human culture, many scholars on the basis of a deep commitment to describing nonhuman animals' realities honestly and dispassionately in the tradition of good, careful, rigorous science have for decades been openly asserting that culture is also a more-than-human phenomenon. An early example was Chimpanzee Cultures (Wrangham et al. 1994a), which openly challenged the fact that in the past "[v]irtually every definition of culture in the social sciences premise[d] human uniqueness ... thus barring any thought of continuity with other species." (Wrangham et al. 1994b, p. 18). Today, literally dozens of other species have been identified as having elements of social transmission that have prompted researchers to use the term "culture."

Beyond science-based claims reminding us that humans are full members of other-than-human groupings, it is the notion of nested communities that, partly relying on such scientific facts but even more significantly relying on our communal abilities, takes us far beyond whatever grace and power scientific viewpoints alone confer on us. Science contributes through evidence-based reasoning about our current physical realities, but our need for the kind of meaning that comes only with connection is what allows us to come home, as it were, to our long human past and our countless human ancestors who long ago noticed that our animality gives each us an immediate, existential connection to other-than-human lives as well as our local place. For those who today notice these connections, the world is "alive" in a great variety of ways.

Is it any wonder, then, that in specific places, we can touch the animality we share with other creatures? In our urban and suburban local neighborhoods, we can notice that we are but one of many "city creatures." (Van Horn and Aftandilian 2015) Such a sense of connection can help override the common phenomenon of city dwellers manifesting only city-constricted senses of self-concern that are one of the diseases of human exceptionalism. But human city dwellers can, with effort, recognize, identify, contextualize and make part of their local community the nonhuman animals that abound in buildings, businesses, underground infrastructure, parks, vacant lots, and myriad other interstices of our urban spaces. Today, there are many human voices drawing upon an astonishingly rich range of resources and arts to explore this distinctive "mixed species community" of living beings.

In rural, less-urbanized areas, nonhuman animals can be far more apparent-they can also set clocks for us through their annual migrations overhead or in nearby woods, rivers and oceans, thereby reminding us of the far-flung places that these members of our larger community inhabit at different times of the year. Such periodic appearances are a profound reminder that our human-centered versions of morality and spirituality ignore so much in the real world, thereby leaving the false, altogether debilitating impression that the larger world is primarily a human place. It is, of course, a truly mixed community of many millions of species.

The presence of other animals, by offering us expanded awareness, helps us recognize yet another way that human exceptionalism creates ignorance, not understanding-our early twenty-first versions of morality are made one-dimensional by their abject human-centeredness. Thereby, these purported guides to developing the extraordinary potential of our human abilities to care about "others" have made many of us dysfunctional. Such human-centered "morality" is truly inadequate as a guide to living in a more-than-human world. Further, the potential that extravagantly human-centered advice has for nurturing humans is meager, affording no help to humans who must cope with our species' now pronounced tendencies to speciesism, a late-twentieth century version of human exceptionalism and similar notions called many different names (Waldau 2001, p. 32). Accordingly, many humans today struggle to learn the complex skills needed to meet the challenge of full self-actualization. Advice that is radically human-centered fares poorly compared to far more robust forms of morality that prompt each of us as an individual to recognize that, for ourselves as well as for our local community and our species as a whole, "self-actualization is possible only as a side-effect of self-transcendence."

Such a challenge looms large for those who seek to puzzle out the past and present of the "animals and religion" intersection, as well as guess in an informed way about future prospects for religiously 
inspired approaches to our fellow animals. It is worthy of note that pieces of this puzzle can be found in a wide variety of places. In our ancient past, the extraordinary notion of ahimsa (usually translated as "nonviolence")

originally applied not to the relationship between humans but to the relationship between humans and animals. Ahimsa means 'the absence of the desire to injure or kill,' a disinclination to do harm, rather than an active desire to be gentle; it is a double negative, perhaps best translated by the negative 'nonviolence,' which suggests both mental and physical concern for others. (Doniger 2009, p. 9)

Consider also an "everywhere" phenomenon, namely, how often "animals" have been mentioned in stories that tell us about religious figures and places-frequent mention of nonhuman animals in such materials is in part attributable to the often-ignored truth that living beings are ubiquitous in the sense of existing in an uncountable number of places, including on every surface, in the soil, throughout the atmosphere and the oceans' every depth, and, of course, on and in our own body and that of every other familiar living being.

The frequent reference to other animals in religious stories is also due to the fact that many human cultures have kept "the animal issue" in the foreground of their moral concern through daily recognition that, as the title of a 1996 book suggests, "wisdom sits in places." (Basso 1996) In these places, as in each reader's local world, the community is, for those who care to notice, more-than-human. One of the many articulate members of the world's indigenous people communities linked humans' future to place and to our ability to speak for the entire living fabric of the Earth.

The future of mankind lies waiting for those who will come to understand their lives and take up their responsibilities to all living things. Who will listen to the trees, the animals and birds, the voices of the places of the land? (Deloria 1973, p. 301)

The question of listening to, as well as speaking for, the whole of the Earth community is an ancient concern that still persists today in a variety of ways, including pleas before the United Nations (Lyons 2003). Marginalized by the dysfunctional forms of human exceptionalism that have now prevailed in policy-making and religious circles of the industrialized societies for several centuries, these "who will speak?" and "who will listen?" challenges remain a formative factor in many small-scale cultures that have not succumbed to an insistent human exceptionalism.

The long tradition of recognizing that humans live in a more-than-human world has a corollary in the notion of nested communities that reach beyond the species line. We belong to families which in the industrialized world increasingly include "companion animal" cats, dogs, horses and many other nonhuman animals. Beyond our families, however, each of us can easily notice as well that some of the communities to which we belong are decidedly multi-species in composition-neighborhoods, local communities, regional affiliations, nations, our ecological niche in a larger ecosystem, and both subcultures and cultures that cross political and social boundaries. We are also members of the ape clade, the taxonomic order of primates, the class Mammalia, the subphylum Vertebrata, the phylum Chordata, the kingdom Animalia, and more. One of the best explorations of how we participate bodily in what might seem highly abstract categories is a detailed explanation of each human's "inner fish," "inner reptile" and "inner monkey." (Shubin 2008)

Recognizing our "nested communities" is more than a great advantage-it is, at one and the same time, both a kind of self-knowledge and a community-based knowledge. Some of our nested communities will on first impression seem remote-we are, in one sense, already "in" these communities, such as ecosystems or the community of Earth's community of air breathers who share a common atmosphere, or the land shared by a continent's land-dwellers, or users of Earth's crucial water resources which we, as animals, take in and give off each day. Yet there are other communities we can choose to join, and others we may choose to leave (as happens when we emigrate from our birthplace, 
or are forced to leave because of socio-political dangers, or freely convert from one religious outlook to another).

Despite the fact that we have natural, common-sense connections to some communities well understood as primarily human, others as primarily animal, and others as truly ecological in nature, it remains a characteristic feature of modern industrial societies that the prevailing ways of speaking in major institutions ignore the animal and ecological. This is true of much of the rhetoric of mainline religious institutions, the concepts and discourse employed in legal systems, and the content prescribed in educational settings that teach human-centered "ethics"—in fact, all of these foreground "business as usual" in which only humans are noticed and taken seriously. Ignoring other-than-human individuals and communities impacted by our decisions is the norm, not the exception. This phenomenon can be problematized on many different grounds, but notice at least that such a narrow approach ignores part of our own nature and heritage-many cultures have held, and some still assert today, that responsible citizenship for an individual requires that she or he move beyond the shallow, un-scientific, logically fallacious dualism "humans and animals."

Responsible citizenship, whether in the form of living religion or a secular movement that chooses a non-religious explanation, also requires frank admissions that the prevailing forms of human exceptionalism rob humans of their connection to most of their natural, nested communities. In this way, human exceptionalism radically (in the etymological sense of going to the root) disadvantages the very living beings (humans) such exclusivist claims purport to honor. Responsible citizenship in the Earth community contrasts greatly with such exclusion, for it means that human animals need, for communal purposes as well as their own development, to acknowledge openly their citizenship in a variety of more-than-human communities. Such an affirmation requires, in turn, an honest, robust recognition of our place as one animal among so many others living in interconnected ways on a diverse and inviting more-than-human Earth.

Such acknowledgments allow us to pose to any institution, including religiously defined ones, a fundamentally ethical question-has this institution helped humans see that each of us is a member of an entire series of nested communities that reach well beyond our local world? Unless an institution can answer affirmatively, there is reason to suggest that the institution is not "living" in the sense of prompting us, as living beings, to look both locally and more broadly. Such an inclusive approach is the only way individual humans can recognize that their personal, full actualization requires forms of self-transcendence that produce benefits of different kinds-for the individual himself or herself, for the individual's family and local community, and yet also for the human species, local fauna, and the larger communities of life like the living, interconnected webs that are one's econiche, ecosystem, and the Earth.

\section{Living Religion Fosters a Stance of Openness to the Possibility of Unlearning Those Inherited Images That Contract Rather Than Expand Our Understanding of Caring for Others}

Questions about whether we recognize our nested communities as reaching well beyond our local world beg all of us to work at understanding the significance of humans' complex religious past and present. Such work has been a feature of the important ferment on "religion and animals" evident in academic circles over the last half-century. But since both the study of "animals" and the study of religion require place-reckoning, which is a form of community-reckoning, any sustained inquiry into these two subjects' intersection must engage the fact that many humans have long felt the need to live as informed members of the more-than-human community. Such an acknowledgement requires exploration of the role human exceptionalism has been allowed to play in the past study of religion and spirituality. Such exploration in turn requires frankness about the ways in which human exceptionalism, including those forms of this exclusion advanced by mainline religious institutions, has misled our modern societies into openly asserting that caring about only humans is both a kind of "common sense" and a defensible moral stance based on an informed view of the world we inhabit. 
Human exceptionalism cannot in any way meet such criteria, which means that claims made in major religious institutions that support human exceptionalism are worth re-examining. As already noted, human lives in an astonishing variety of daily acts and emotions reveal fully that we are animals. Similarly, exploration of the world in which we and our forebears have been living reveals that when nonhuman lives are examined realistically, such examination readily reveals that the animal world is richly endowed with nonhumans who are, like humans, bearers of consciousness. Such an examination also confirms that most human cultures across time and place have acknowledged our own animality and the importance of being informed about other animals' actual features. Both our deep past and our present sciences, then, reveal richly that we know now, just as we have long known, that some nonhuman species are endowed with bodies, brains, and distinctive social and individual lives that confer on individuals forms of intelligence, caring and so much else that commands fascination and respect. We thus know from diverse sources-our own observations and the heritage we received from past human generations - that humans can thrive through caring about beings outside our own species. We also know that we need a biodiverse, multispecies world as our natural home and a condition of our own health.

Yet many of our human communities in the last few centuries have been increasingly dominated by an exclusivist narrative that attempts a justification of human domination. Consider how the logic of human exceptionalism lurks within the influential idea of humans' moral growth evidenced by an expanding moral circle. The prominent nineteenth-century historian of morals William Edward Hartpole Lecky famously observed,

At one time the benevolent affections embrace merely the family, soon the circle expanding includes first a class, then a nation, then a coalition of nations, then all of humanity, and finally, its influence is felt in the dealings of man with the animal world. (Lecky 1884, pp. 100-1; Singer 1981, p. xiii)

This narrative of expansion-first, the individual's family, followed by class, nation, coalition of nations, all of humanity, "and finally ... the animal world" - appeals because it is simple and hopeful. Further, the image might be said to help us see key features of the moral lives advocated within human communities-human individuals may first begin to care by focusing on the nearby living beings, like one's family and local community, but a natural expansion of our abilities to care and protect is possible. The image also helps call attention to the important fact that ideas about ethics found in human communities have not been static. More specifically, there is evidence for arguing that a long-term trend across millennia has been inclusion of some previously marginalized humans within the protective boundaries of what is rightly called the moral circle. Finally, we may also relate to Lecky's image because it alerts us to the great importance of stopping our species' horrific record of causing human-on-human harms.

But the appeal of this image has beguiled us-true as it is that, in one era after another, societies have changed their notion of "the others" that deserve protecting. The expanding circle image fails to help us to see that the trajectory of humans expanding their care for "others" is far more complicated than Lecky's account of an expanding circle suggests. Particularly complicated is that Lecky's trajectory of expansion masks what actually happened in our deep past-many cultures long ago protected some of their local free-ranging wildlife in noteworthy ways while not protecting all the neighboring humans. Further, some ancient concerns for nonhumans, such as condemnations of gratuitous cruelty, persisted for millennia but in the modern era have been eroded greatly (as happens in the increasingly widespread practice of mass confinement of farm animals known as factory farming). Indeed, it is highly likely that (i) if we allocated one vote to every distinctive human culture that ever existed, and (ii) then took a poll of these cultures on whether nonhuman animals should be (and in fact were) protected in the moral circle that this group taught to their own children, (iii) we would find that a large majority of human cultures "voted" that many different kinds of nonhuman animals were deemed to belong within the group's moral circle. 
Lecky's image of an expanding circle, then, fails to alert us to our own history, for the expansion Lecky described was not, in fact, the actual pattern that our own cultures followed. Many of our ancient forebears actively protected some nonhuman animals even as they very clearly did not protect their neighboring humans, let alone all humans. Further, many (although not all) early civilizations permitted many forms of human-on-human violence, including notoriously the domination of women, or the practice of slavery and rape when they conquered competing human societies.

Lecky's image also fails on the question of local place. The image masks that place has from time immemorial mattered to humans even though in today's industrialized societies many people have lost this important sense of connection. We do not have to travel far back in our own cultural heritage to discern that place mattered not in the modern sense of owning real property, but in the sense that "wisdom sits in places" given names because those places held pivotal shared memories for our ancestors, thereby establishing a sense of continuity and even sacred presence (however the reader wishes to define this term).

The tenor of today's human exceptionalism, then, marks a truly fundamental break with key attitudes that prevailed in most human societies for millennia. The peculiarity of this modern dismissal is reflected in a poignant observation made by Matthew Scully, a former speechwriter for an American president, in the opening pages of a book addressing modern challenges.

... no age has ever inflicted upon animals such massive punishments with such complete disregard, as witness scenes to be found on any given day at any modern industrial farm. (Scully 2002, p. x)

The suggestion that our concern for "others" has been broadening in the manner of an expanding circle is, thus, less description than prescriptive nicety that masks the all-too-familiar "humans first and foremost" trope that is the essence of human exceptionalism. Such a narrative obscures the key fact that today's industrialized societies have lost much wisdom about why being a responsible citizen in a more-than-human world afford forms of self-transcendence that cannot be imagined, let alone achieved, under a life guided by human exceptionalism.

Living religion, because it is pervaded by the inevitable question "whom might I care for, given my finite abilities as a living being?", nurtures a more open notion of caring. It thereby raises the important possibility that we should, if we wish to fully actualize human potential, at times take the initiative to unlearn some of our inherited images. Unlearning of this kind would in turn allow us to provide our children with a more honest appraisal of our own species' mixed record as ethical animals. There is good news in all of this, of course, for such unlearning affirms that each human has the ability to ask about their own multi-species local world, "Who are the others about whom I might care?", and then to expand our robust ability to care, and thereby make community, more widely as we live our lives on this more-than-human Earth.

Something else that we can recognize as true today is deeply sad-in the last few centuries, we, as a species, have decidedly failed our ancestors' vision that humans should be responsible citizens in a more-than-human world. This failure forces a poignant question-does our larger human community have the ability today to develop and sustain forms of life, whether living religion or living law or living ethics, that permit individuals to actualize their potential for relating to our local community and place? In the spirit of this possibility, consider how small-scale societies can teach us options about the who, what and how of "personhood." An astonishingly large majority of those indigenous human cultures whose lives have been closely intertwined with their local natural world have viewed other animals as, in their actual lives, "active and reactive social others, alternately collaborating in and obstructing the designs" of our own species. (Brightman 1993, p. 2)

Notice how fully local this notion of personhood is. Notice as well how such notions, often associated with small-scale, indigenous religious traditions, can be a form of living religion as well.

Personhood, then, is not primarily a separateness from others but "a relationality," that is, it comes about by paying attention to and being in relation to the living beings, human and 
nonhuman alike, in one's local world. Most interesting from the vantage point of Animal Studies is that it is "work toward relatedness, especially in knowing animals" that makes such relation-built personhood an "achievement." What humans can learn is significant if we "join the dance of life in the knowledge that all of us-humans and nonhumans-are bound together by networks that feel more like kinship than we can ever have imagined before we encountered the sacred ecology of our Native American predecessors."

(Waldau 2013, pp. 191-92; Grim 2006, p. 380; Harrod 2000, p. 138)

Discerning how to live such an insight while a citizen of a modern, industrialized society is not a simple challenge. The insights of small-scale societies are framed for life in their own local world. They are, thus, dependent on specific contexts that can be radically different from modern urban, suburban and rural settings. Further, the expression of such insights about how to live in relation to one's local world are characteristically "understood ... on the basis of their ceremonial life." (Prentiss 2003, p. 64) Such comments reflect the enormous challenges any modern human faces as she attempts to work with even the simplest features of the religious/spiritual/wisdom traditions developed long ago by another group in another place. There are clues, as well as much well-developed thinking, about how to go forward, an example of which are the nuanced ecological insights set out by the remarkably fecund movement known as "religion and ecology."

Consider how tolerance and possibilities of co-existence are heartbeat concerns of two simple statements that any individual can make.

My religion is one among many others.

My species is one among many others.

Pairing the modest humilities that drive these statements allows one to discern two productive forms of self-transcendence-first, humility regarding one's own judgment about whether or not, and if so just how, to be religious or spiritual; and, second, the humility needed to develop and then express a willingness to notice and take seriously nonhuman "others" who live in the local place where each of us lives. Living religion draws life from such humilities, which is enriched further as one acts and cares within, first, one's local world as a mixed, multi-species community, and, second, a mixed society where those with different religious orientations co-exist alongside humans who choose not to be religious or spiritual in any traditional sense. The capacity to co-exist in either manner features a humbleness that challenges arrogant exclusions that prevail when a human makes one's own features-whether gender, race, ethnicity, religion, or membership in one's own species-the measure of all things.

\section{Living Religion Affirms Spirituality as This Worldly}

In the spirit of unlearning, tolerance and co-existence pursued to remedy the poverty created by human exceptionalism, what might we say about religious approaches in a local place? The elegant connections possible by virtue of the fact that humans can recognize ourselves as members of more-than-local communities in no way eclipse the primacy of the local world. In simple, direct, daily ways, the local question is rooted in the insight that, for animals of all kinds, "there never was an is without a where." Further, that we are capable of noticing our membership in a series of nested communities, in fact, enhances the foundational significance of knowing one's local world well enough to act responsibly in daily life. Correspondingly, when humans recognize how full their own lives can be in their local world, they enhance their power to notice our membership in regional, ecological and global communities as well. Indeed, without an anchor in a local place, our daily lives risk deracination and drifting out of touch with our own eminently animal realities.

To engage what being a local animal means for spirituality, consider a phenomenon evident in the way modern English speakers discuss religion-synonyms commonly listed for the adjective "religious" often have distinctly nonphysical connotations. Here are more than a dozen synonyms for "religious" that play down in some way, sometimes to the point of denial, our animal realities and local place. 
discarnate, disembodied, ethereal, extramundane, ghostly, heavenly, immaterial, incorporeal, intangible, nonmaterial, nonphysical, platonic, supernal, unfleshly, unphysical

Contrast a second set of synonyms with an eye to how other synonyms for "religious" can, if positively interpreted, affirm in some way our animal realities and local place.

airy, devotional, devout, divine, holy, pious, pure, sacred, saintly

With only a modicum of imagination, each synonym in this second set can apply to those humans who, having chosen a particular form of a religious or spiritual life, thrive in a local place. Being embodied as one pursues a chosen life is not an impediment, but instead a pre-condition of the possibility of pursuing spirituality or religious practice. Consider in the same spirit an affirmation of the foundational nature of humans' animality implicit in a series of recitations that the historical Buddha recommended the men and women in his monastic community use during their daily meditation. Rather than distancing humans from other animals, the following five acknowledgements plainly reveal that the one reciting these affirmations is alive in the manner of Earth's other animals.

I am of the nature to grow old.

I am of the nature to have ill health.

All that I hold dear and every one I love are of the nature to change.

My actions are my only true belongings. (Hanh 2000, p. 35)

The first three affirmations acknowledge "I am alive now but, like all other living beings, will decline," while the fourth reveals communal abilities shared with many other animals, and the fifth connects the reciter to the fate of being subject to karmic consequences which Buddhists assumed was the lot of all living animals.

Whatever one thinks of such claims, it is crucial to note that religion as one of humans' macro achievements across time and place (one that rivals or exceeds the importance of other macro human achievements such as science, ethics, law or education) is wrongly charged as always ignoring humans' animality or our nonhuman neighbors. The record of religions collectively is, as any serious study will readily show, decidedly mixed when answering key questions such as "are humans animals?" and "how should humans treat living beings outside our own species?" Importantly, the same conclusion applies to the overall record evident in our sciences, our ethical/moral accounts of our lives, our legal systems, and our formal education.

One thing that should be evident even to skeptics about the relevance of any religious or spiritual tradition to their own life is that while religious options for humans are extremely diverse, virtually all of them come in a version that can be potentially powerful in choosing to live in terms of a perspective that acknowledges humans are one kind of animal in a world full of many kinds of living beings. Religion and spirituality, then, can clearly be "living" in a sense that is relevant to a human individual's full life in a local place and to whatever broader horizons and larger communities one chooses to recognize. Just as clearly, however, those who explore the societies of today's industrialized and post-industrialized societies can easily find forms of religion and spirituality that create communities which are bastions of exclusion and small-minded human exceptionalism that in no way qualifies as "living religion" as the term is developed in this essay.

\section{Religious Thinking about Other Living Beings Will Be Richer If It Is Anchored in Good Factual, Observation-Based Information}

The discussion above has assumed without argument that religious thinking about the "animal issue" will be richer and of more value to any religious individual or institution if it is anchored in good factual/observation-based information. Even for those readers who find claims about the importance of observation-based information to be a common-sense proposition, the issue of other animals' realities is challenging for a variety of reasons, two of which are explored here. 
First, our view of those "realities" that surround us in our local world will always be incomplete, for we as individuals in daily life can attend to only those aspects of our local world that our limited senses of sight, touch, hearing, smell and taste allow us to access. In this sense, the world we experience is, like the world any other animal experiences, not the whole story, as it were. But our species is particularly communal, which fact, in conjunction with our great capacities for pattern recognition, gives each of us the chance to learn various traditional accounts about our world's animals (both human and nonhuman) that carry both wisdom and high degrees of accuracy.

Even the best generalizations about other animals are, to be sure, social constructions, and thus subject to human error and manipulations, as are our accounts of other humans. What can be particularly difficult is that many people inherit by way of culture ways of talking about other living beings (whether human or nonhuman) that are thoroughly dismissive because they are premised on a foundation of negative generalizations rather than actual encounters.

In such cases, some rules of thumb may be applied-when a human group manifests prominent dismissive tendencies toward the vast majority of their neighboring nonhumans, they will also dismiss other groups of nonhuman that they do not know. Further, they will also dismiss, even deny, their own human animality. It is true that some humans who assert human exceptionalism do favor certain nonhumans, such as their owned companion animals or a particular species of wild animal they hold to be iconic, but such favoritism can, because it also is a form of human-centeredness, easily co-exist with rabid human exceptionalism.

Second, each of us has been exposed to inherited arrogance because of the dominance of human exceptionalism in so many major human enterprises (for example, law, science, education, and ethics). This is yet another reason that unlearning is a valuable skill to acquire, although it is obviously a subtle, possibly politically risky aptitude to acquire when human exceptionalism is the dominant narrative in your culture's education, business, politics and mainline religious institutions. As with challenging any human's rank prejudice against a disfavored human group, the key when problematizing a dismissal of some specific group of nonhuman animals is to subject the negative generalization that undergirds the dismissal to both critical thinking and patient empirical observation over time. With such an effort, unlearning can grow, especially if it is nurtured by straightforward questions that have a power not only through an evidence-driven answer, but also in their very asking. In each of the following, what is powerfully in the wings, as it were, is the life-expanding possibility that unlearning may be needed.

Were the claims I was taught about other animals observation-based?

Or were such claims received by me from other humans who simply passed along claims they inherited and which, if examined carefully, reveal that the view in question was in no way the product of a diligent, good faith search for what humans might know about the animals being addressed?

The power of these questions can be expanded by two other questions that every human can ask-what is my local world like? and what has been my own experience of other animals?

Other helpful perspectives can be gained, of course, through inquiries regarding what other cultures have suggested about humans' relationship to other animals. The very breadth of such an inquiry and the kaleidoscope of answers to be found in every society help any inquiring human recognize a key feature of each human life. Each of us, by virtue of being raised in this or that place in a particular subculture or culture, is born into a worldview and cultural synthesis that shapes one's views long before one begins to talk, let alone think critically on this most vivacious of topics. Just as the kinds of humilities discussed above make possible productive forms of self-transcendence, so does thinking about the possibility of stepping away from those negative generalizations that one has inherited by way of family or culture regarding both other humans and other-than-human animals. We can aspire to such explorations precisely because we are a kind of animal capable of thinking critically about our heritage. 
The power of these and so many other questions about our own animality opens up the possibility of discovering that humans in an astonishing number of cultures have, in their own local world/place, been surprisingly interested in other-than-human neighbors as "active and reactive social others." It does not surprise us then to learn that many people today also are deeply interested in both their local nonhuman neighbors and more abstract issues of the kind reflected in these recent book titles.

Are We Smart Enough to Know How Smart Animals Are? (De Waal 2016)

What a Fish Knows (Balcombe 2016)

The Genius of Birds (Ackerman 2016)

Not only is our local world filled with these or other kinds macro animals (that is, animals large enough for our primate eyes to identify them as discreet individuals), but there are an incalculably greater number of microorganisms in our local world (indeed, on and in each of us in numbers that truly astonish our macro animal minds). A common statement in scientific and journalistic sources is that "the bacteria residing within each human body outnumber human cells by a factor of 10 or more." (Sender et al. 2016, p. 337) Allied with us in life are, of course, plants as well, connections which lend themselves to descriptions that can be as lyrical as they are scientific (Kimmerer 2013; Haskell 2017).

Each of us, then, lives as one individual who shares a surpassingly complex local world in which we are linked in astonishing ways to many other forms of life found in the nested but ever-so-diverse communities that host not only our human abilities but also our fellow animals' differing forms of intelligence, caring and even genius. Good information about this kaleidoscopic complexity creates an eminently ethical challenge at the heart of living religion—given humans abilities and finitudes and problematic heritages, about whom and what will we care as we live in a truly diverse community of life in which we are not the only consciousness-bearing animals in our local world?

\section{Religiously Inspired Claims about Humans' Relationships with Other Living Beings Will Inevitably Reflect Humans' Own Animal Abilities and Finitudes}

Many ancient claims about humans in relation to the living beings outside the human species reflect, as did the historical Buddha's advice to his monastic community, what today is a consensus position in all modern sciences, namely, that humans are as fully animal as is any nonhuman animal. A study of human cultures reflects widespread awareness that this conclusion is easily discerned through even the most casual observations, but also through communal stories that affirm overlapping traits between, on the one hand, humans and, on the other hand, many nonhuman animals-a classic example of such recognition appears in the Hebrew Bible/Old Testament Book of Ecclesiastes.

For the fate of the sons of men and the fate of beasts is the same; as one dies, so dies the other. They all have the same breath, and man has no advantage over the beasts; for all is vanity. All go to one place; all are from the dust, and all turn to dust again.

(RSV 1952)

Recognition of other similarities abound as well—origin stories told within individual cultural traditions very often present nonhumans as having a genesis that is, if not identical, at least comparable to that ascribed to the human community whose story is being told. Other animals are frequently described as created by the same creator divinity, and aware, even worshipful, of that divinity. Especially common are claims that testify to the observable fact that other animals have communities, share social communication, and often behave in ways that overlap with human behavior (a well-known example appears in the Qur'an at 6:38, which in the Ahmed Ali translation (Ali 1984) reads, "There is not a thing that moves on the earth, no bird that flies on its wings, but has a community of its own like yours").

Consider how a claim about human emulation of nonhuman animals richly confirms that we take advantage of the animality we share with certain other animals. In Made for Each Other: The Biology of the Human-Animal Bond (Olmert 2009), Meg Olmert offered science-based insights into humans' own 
animality as humans long ago imitated group hunting techniques of other social mammals, and then later partnered with other animals whose descendants are the one billion dogs who share the Earth with us today.

Thousands and thousands of years ago, our ancestors dreamed of unions with animals that would make them stronger, braver, faster, and wiser. In their dreams they surrendered their humanity and took on the shape and power of wild beasts. It was these mergers with the animal form and spirit that humans believed to be their ultimate achievement. They knew it was only with the help of animals that they could navigate this life and cross over into the next.

(Olmert 2009, p. ix)

Olmert's framing of humans as gifted animals working with other differently gifted nonhuman animals provides an account of our human past which clearly identifies us as eminently one animal among others in a multispecies world. It is humans' own animal needs and abilities that confer on us the capacity to become "plain members and citizens" of a far-more-than-human world. Olmert suggests that there were significant benefits that flowed from humans' efforts to observe, then selectively ultimately bond socially with, certain of our neighbor animals. The biological bases of this bonding require that Olmert touch on multiple topics, including the fact that humans have not only brain cells (mirror neurons) in common with many other mammals, but also share a powerful hormone (oxytocin) that acts as a "neurotransmitter" in many vertebrates' brains (the biology and chemistry are extraordinarily complex, involving many other key, overlapping substances). The connection of humans' animality to that of other vertebrates could hardly be more apparent than these shared underlying biochemical realities that prompt connections between members of different species.

The widespread recognition of such a diverse range of overlaps is not too surprising given the foundational place accorded in modern biological sciences to extensive evidentiary confirmation of humans' evolutionary connections to other animals. Particularly revealing about the extent of such connections is the fact that each human has a body, as do all other mammals, well described as having "an inner fish" and an "inner reptile." (Shubin 2008) Further, recognition of our own species as one of many different animal communities that comprise a shared, more-than-human world is but one of the ways that human intelligence has consistently shown remarkable gifts at pattern recognition (evident in the way so many human activities build on our predecessors' uncanny ability to develop observation-based astronomical knowledge into calendars, and the constant string of advances in ancient cultures' sophisticated mathematical reasoning). These modern "discoveries" underscore why ancient humans so consistently took it as common sense that some other animals must be understood as bearers of consciousness in order to understand the patterns evident in their lives. Ancient humans were, likewise, not shy about concluding that the animal world is full of communal beings who, also like humans, feature individualized, distinctive personalities.

Our ancient human forebears also widely hypothesized that some other animals were cultural beings. It may be the case that we, as extraordinarily social primates, are stimulated to notice such phenomena in other animals because each of us has robust, mammal-sourced capabilities for caring about (i) our immediate family and (ii) our local acquaintances, community and place. Such traits can be complicated, for we are also members of the subset of the Earth's animals who are radically subject to political coalitions and rivalries as is the case with many other social mammals (De Waal 2016). Finally, consider the following observation about particular animals used in our modern sciences to illuminate humans' psychological realities.

The behavior of rats in cages may be the single largest contributor to the corpus of psychological knowledge. In most cases, the rat itself is not of interest: the research isn't about rats per se. Surprisingly, it's about humans.... [T] he millions of responses by millions of laboratory rats, Rattus norvegicus, have greatly informed our understanding of human psychology. (Horowitz 2009, p. 27) 
That our species has now a centuries-long history of using rats and other nonhuman animals (and, sadly, humans at times as well) in scientific experiments designed primarily to shed light on humans' psychological realities testifies strongly to commonalities we have with our cousin mammals and other, more evolutionarily distant cousins. There are, of course, many thinkers inside and outside religious communities who have challenged the morality of such scientific practices.

These and other overlaps relatively easily discerned between humans and so many other animals suggest an important strategy in our attempts to live well-attempts to recognize who and what we are will be greatly enhanced if we also explore fully our own animal features as they manifest within humans' long-standing inclination to religion and, of course, virtually any other common human activity. Since our music and dance originated in imitation of other animals, might we wonder whether our religion, sciences, ethics, legal systems, and education did as well?

\section{The Achievements We Know as Our Species" "Religions" and "Spiritual Traditions" Are in Fact the Creation of Animals}

To understand the final thread in this tapestry, reflect on your own formal and informal education regarding the meaning of "animality." Were you introduced early to the dualism "humans and animals"? Today, in every level of formal education, this dualism functions as an organizing conceptual scheme for presentations about animate living beings. One may also learn the straightforward scientific fact that we ourselves are mammals and have even closer relatives in the primate family. But rarely has the modern educational world on its own broken through to the fact that this dualism is a false narrative held in place by another fact, namely, that we are, ironically, tradition-bound animals repeating the "human and animals" mantra that is the centerpiece of so much in modern education. In even those domains that pride themselves on how they foreground forms of critical thinking (philosophy, ethics, law, economics), the dualism is treated not as a proposal, but as the equivalent to the axioms that govern a mathematical science like geometry.

As a teacher, however, I experienced that if students were given a chance to share their "personal archeology"; that is, what they recalled if they dug down to the earliest level of their recollections about encountering nonhuman animals, the educational dynamics became startlingly more active. The students leaned into, rather than away from, these personal archeology sessions. Something in the exercise was also prompting them to listen carefully, according each other a level of respect and attention as each personal archeology was explored.

At all levels of formal education, a simple fact is almost always hidden in plain sight-the achievements we know as our species' hallmark achievements are in fact the achievement of an animal group. This conclusion is reached by what primate minds regard as a simple, direct line of reasoning-since humans are primates and mammals, as fully animal as are any other primates or mammals, then a conclusion wanders onto the stage of modern humans' consciousness-our achievements, including our many religions, are animal creations. And once one openly considers this conclusion, a sibling possibility soon invites our attention, namely, the possibility that religious phenomena cannot be fully understood without a robust acknowledgement that humans' animal abilities and finitudes are foundational features of the what and how of humans' very diverse religions and spiritual aspirations.

Even if the reasoning process that leads to this conclusion is relatively uncomplicated, there is reason to listen after making such a claim. In my experience, many deeply spiritual people do not approve of religion being identified as "animal." Religious phenomena are so notoriously diverse that it has become common when studying religion to acknowledge that defining "religion" is perilously hard, to point of being impossible. This is especially so if the task one has set for oneself is to define religion in a way that a majority of listeners in a classroom or a public lecture, let alone a gaggle of scholars or a majority of people, would find acceptable.

Whatever the cause of the chaos that so commonly prevails whenever the primary focus of a discussion is the history and/or present state of human fascination with religion and spirituality, 
extraordinarily diverse human inclinations will no doubt long be a feature of the terrain that we, as human animals, must cross as we live in and shape our local worlds during the coming centuries. What seems especially promising to me is that there are possibilities for understanding much about our animal realities if a broad range of human individuals and communities engage the challenging topic "animals and religion"-indeed, it seems to me likely that exploring this topic can continue to stimulate reflection of a kind that produces classic comments about animal-related issues such Ecclesiastes 3:19-20, Claude Lévi-Strauss's "good to think" observation (Lévi-Strauss 1963, p. 89), or Jacques Derrida's "The animal looks at us, and we are naked before it. Thinking perhaps begins there." (Derrida 2002, p. 397)

It is also worthy of note that debates about religion go forward in the face of a long history of many different religious traditions asserting that some nonhuman animals pay attention to religious matters. (Patton 2000) As to whether any nonhuman animals have ever had a spiritual side, our ability to provide an answer is subject to the same objection that can be made to many claims about human animals-because we cannot be absolutely certain about the content of other humans' experience, including their religious claims, we are similarly situated (or disadvantaged) with regard to all nonhuman animals as well.

\section{Conclusions}

Since we are animals beset with finitudes of many kinds, we need cautious, careful, communal exploration of all that we claim to "know." In the matter of what fairly counts as "living religion," caution is also in order because even our important critical thinking skills are at risk of being employed in ways that reflect confirmation bias (that is, lead to the conclusions one wanted at the outset of an investigation). My own views on living religion are agenda driven-I want religious traditions to live out their possibilities of compassion, humility, connection, and community in ways that are inclusive of the animalities to be encountered in the world, including that of my own species.

The recognition "we are animals" is important to grasping key achievements that are within each human's reach, including (i) recognizing the vast, varied phenomena of the human species' many religions; (ii) choosing a version of life, whether religious or not, that is "living" in the sense used in this paper; and (iii) realizing that for the human animal, there is no self-actualization without self-transcendence. My hope is that studying "animals and religion" helps humans generate good faith discussions about the entire spectrum of humans' engagement with the Earth's living beings, and thereby models what it means to be a responsible citizen in a more-than-human world.

Funding: This research received no external funding.

Conflicts of Interest: The author declares no conflict of interest.

\section{References}

Abram, David. 2010. Becoming Animal: An Essay on Wonder. New York: Pantheon.

Ackerman, Jennifer. 2016. The Genius of Birds. New York: Penguin Press.

Ali, Ahmed. 1984. Al Qur'an. Princeton: Princeton University Press.

Balcombe, Jonathan. 2016. What a Fish Knows: The Inner Lives of Our Underwater Cousins. New York: Scientific American/Farrar, Straus and Giroux.

Basso, Keith H. 1996. Wisdom Sits in Places: Landscape and Language among the Western Apache. Albuquerque: University of New Mexico Press.

Berry, Thomas. 2006. Loneliness and Presence. In A Communion of Subjects: Animals in Religion, Science, and Ethics. Edited by Paul Waldau and Kimberley Patton. New York: Columbia University Press, pp. 5-10.

Bird-David, Nurit. 1999. 'Animism' Revisited: Personhood, Environment, and Relational Epistemology. Current Anthropology 40: S67-S91. [CrossRef]

Brightman, Robert A. 1993. Grateful Prey: Rock Cree Human-Animal Relationships. Berkeley: University of California Press. Buber, Martin. 1958. I and Thou. New York: Charles Scribner's Sons. First published 1923. 
Buell, Lawrence. 2011. American Literature and the American Environment: There Never Was an 'Is' without a 'Where'. In The Harvard Sampler: Liberal Education for the Twenty-First Century. Edited by Jennifer M. Shephard, Stephen Kosslyn and Evelynn M. Hammonds. Cambridge: Harvard University Press, pp. 32-56.

Catechism of the Catholic Church. 1994. Catechism of the Catholic Church. London: Geoffrey Chapman.

De Waal, Frans. 2016. Are We Smart Enough to Know How Smart Animals Are? New York: W. W. Norton.

Deloria, Vine. 1973. God is Red. New York: Delta.

Derrida, Jacques. 2002. The Animal That Therefore I Am (More to Follow). Translated by David Wills. Critical Inquiry 28: 369-418. [CrossRef]

Doniger, Wendy. 2009. The Hindus: An Alternative History. New York: Penguin Press.

Fernandez, James W. F. 1995. Meditations on Animals-Figuring Out Humans. In Animals in African Art. Edited by Allen Roberts. New York: The Museum for African Art, pp. 1-9.

Frankl, Viktor E. 1992. Man's Search for Meaning: An Introduction to Logotherapy, 4th ed. Boston: Beacon Press.

Grim, John. 2006. Knowing and Being Known by Animals: Indigenous Perspectives on Personhood. In $A$ Communion of Subjects: Animals in Religion, Science, and Ethics. Edited by Paul Waldau and Kimberley Patton. New York: Columbia University Press, pp. 373-90.

Hall, David D., ed. 1997. Lived Religion in America: Toward a History of Practice. Princeton: Princeton University Press. Hanh, Thich Nhat. 2000. The Plum Village Chanting and Recitation Book. Berkeley: Parallax Press, p. 35.

Harrod, Howard L. 2000. The Animals Came Dancing: Native American Sacred Ecology and Animal Kinship. Tucson: University of Arizona Press.

Haskell, David George. 2017. The Songs of Trees: Stories from Nature's Great Connectors. New York: Penguin.

Horowitz, Alexandra. 2009. Inside of a Dog: What Dogs See, Smell, and Know. New York: Scribner.

Kimmerer, Robin Wall. 2013. Braiding Sweetgrass: Indigenous Wisdom, Scientific Knowledge, and the Teaching of Plants. Minneapolis: Milkweed.

Lecky, William Edward Hartpole. 1884. History of European Morals: From Augustus to Charlemagne, 6th ed. Longmans Green: London, Volume 2.

Leopold, Aldo. 1991. The Land Ethic. In A Sand County Almanac, with Essays on Conservation from Round River. New York: Ballantine, pp. 103-6. First published 1949.

Lévi-Strauss, Claude. 1963. Totemism. Translated by Rodney Needham. Boston: Beacon.

Luther Standing Bear. 1998. Indian Wisdom. In The Great New Wilderness Debate. Edited by Baird J. Callicott and Michael P. Nelson. Athens: University of Georgia Press, pp. 201-6. First published 1933.

Lyons, Oren. 2003. Our Mother Earth. In Seeing God Everywhere: Essays on Nature and the Sacred. Edited by Barry McDonald. Bloomington: World Wisdom, pp. 103-6.

Olmert, Meg. 2009. Made for Each Other: The Biology of the Human-Animal Bond. Cambridge: Da Capo Press.

Orsi, Robert. 1985. The Madonna of 115th Street: Faith and Community in Italian Harlem, 1880-1950. New Haven: Yale University Press.

Patton, Kimberley C. 2000. 'He Who Sits in the Heavens Laughs': Recovering Animal Theology in the Abrahamic Traditions. The Harvard Theological Review 93: 401-34. [CrossRef]

Prentiss, Craig R. 2003. Religion, and the Creation of Race and Ethnicity: An Introduction. New York: New York University. Rachels, James. 1991. Created from Animals: The Moral Implications of Darwinism. New York: Oxford University Press. RSV. 1952. The Bible Containing the Old and New Testaments. Swindon: The British \& Foreign Bible Society.

Santa Clara University. n.d. What is 'Living Religion'. Available online: https://www.scu.edu/livingreligions/ about-the-lrc/what-is-living-religion/ (accessed on 9 April 2019).

Scully, Matthew. 2002. Dominion: The Power of Man, the Suffering of Animals, and the Call to Mercy. New York: St. Martin's Press.

Sender, Ron, Shai Fuchs, and Ron Milo. 2016. Are We Really Vastly Outnumbered? Revisiting the Ratio of Bacterial to Host Cells in Humans. Cell 164: 337-40. [CrossRef] [PubMed]

Shubin, Neil. 2008. Your Inner Fish: A Journey into the 3.5-Billion-Year History of the Human Body. New York: Pantheon Books.

Singer, Peter. 1981. The Expanding Circle: Ethics and Sociobiology. Oxford: Clarendon.

Tucker, Mary Evelyn. 2006. A Communion of Subjects and a Multiplicity of Intelligences. In A Communion of Subjects: Animals in Religion, Science and Ethics. Edited by Paul Waldau and Kimberly Patton. New York: Columbia University Press, pp. 645-47. 
Van Horn, Gavin, and Dave Aftandilian, eds. 2015. City Creatures: Animal Encounters in the Chicago Wilderness. Chicago and London: University of Chicago Press.

Vroom, Hendrik. 1993. Chicago 1993 The Parliament of the World's Religions. Studies in Interreligious Dialogue 3: 114-20. [CrossRef]

Waldau, Paul. 2001. The Specter of Speciesism: Buddhist and Christian Views of Animals. New York: Oxford University Press.

Waldau, Paul. 2013. Animal Studies: An Introduction. New York: Oxford University Press.

Wrangham, Richard W., William C. McGrew, Frans B. M. de Waal, and Paul G. Heltne, eds. 1994a. Champanzee Cultures. Cambridge: Harvard University Press.

Wrangham, Richard W., Frans B. M. de Waal, and William C. McGrew. 1994b. The Challenge of Behavioral Diversity. In Champanzee Cultures. Cambridge: Harvard University Press, pp. 1-18.

(C) 2019 by the author. Licensee MDPI, Basel, Switzerland. This article is an open access article distributed under the terms and conditions of the Creative Commons Attribution (CC BY) license (http://creativecommons.org/licenses/by/4.0/). 